\section{Maps as the Tools of Representation and Design in Architecture}

Gülşah Güleç¹, ORCID: 0000-0002-8041-2018

\section{Keywords}

Map; Mapping; Architectural

Representation; Architectural

Design; Creative Map

\section{Article Information}

Received:

17.09.2020

Received in Revised Form:

17.01.2021

Accepted:

22.01.2021

Available Online:

30.01.2021

Article Classification:

Research Article

\section{Contact}

1. Department of Architecture, Gazi University, Ankara, Turkey gulsahgulec@gazi.edu.tr 


\section{Mimarlıkta Temsil ve Tasarım Araçları Olarak Haritalar}

Gülşah Güleç¹, ORCID: 0000-0002-8041-2018

Öz

$\mathrm{Bu}$ makalede, haritanın mimarlıkta yalnızca temsil değil aynı zamanda tasarım aracı olduğu ortaya koyulmaktadır. Bununla birlikte, harita genellikle temsil aracı olarak görülmektedir. Ancak haritanın mimari tasarım sürecinde araçsallaştırılması onun bir tasarım aracı olmasını ve tasarımı oluşturmasını sağlamaktadır. Böylece yaratıcı haritalar ortaya çıkmıştır. Makalede yaratıcı haritalar zihinsel, kuramsal, şekilsel, anlatımsal, alg1sal, imgesel, işlevsel, dizinsel, ilişkisel ve etkileşimsel haritalar olarak tartışılmaktadır. Zihinsel haritalar, kentsel ve mimari mekânın yalnızca fiziksel değil aynı zamanda zihinsel bir oluşum olarak ele alınmasını sağlamıştır. Kuramsal haritalar, mekânın kuramsal ve tasarımsal oluşumunu ortaya koymaktadır. Şekilsel haritalar, bu oluşumu kentsel boşluk ve doluluk ilişkisine dayandırmıştır. Anlatımsal haritalar, tasarımların bir dizi anlatıya ve olaya göre oluşmasına ortam hazırlamaktadır. Algısal haritalar, mekân algısının ve tasarım anlayışının değişmesine yol açmaktadır. İmgesel haritalar, tasarımları etkisi ve hayal gücü yüksek olan imgelerle oluşturmaktadır. Isşlevsel haritalar, tasarımların işlevler arasında kurulan ilişkilere göre oluşmasını sağlamaktadır. Dizinsel haritalar, tasarımları oluşturan işlevsel, biçimsel ya da bağlamsal ilişkileri bilgisayar teknolojileri aracılığıyla bir dizi veri haline getirmiştir. İlişkisel haritalar, dizinlenen veriler arasında çok değişken ilişkilerin olduğunu; tasarımı bu ilişkilerin oluşturduğunu göstermiştir. Etkileşimsel haritalar ise tasarımı oluşturan ilişkilerin değişmesine ve değişen ilişkilere göre tasarımın yeniden şekillenmesine aracılık etmiştir. Bu nedenle, makalede haritayı mimarlık alanında yalnızca bir temsil aracı olmaya indirgeyen bakış açısının değişmesi gerektiği belirtilmektedir. Mimarlıkta harita, temsil ve tasarım aracı olduğunda yaratıcı bir araç haline gelmektedir.

\section{Anahtar Sözcükler}

Harita; Haritalama; Mimari Temsil;

Mimari Tasarım; Yaratıcı Harita

\section{Makale Bilgileri}

Alind1:

17.09.2021

Revizyon Kabul Tarihi:

17.01.2021

Kabul edildi:

22.01.2021

Erişilebilir:

30.01.2021

Makale Kategorisi:

Araştırma Makalesi

\section{İletişim}

1. Mimarlık Bölümü,

Gazi Üniversitesi, Ankara, Türkiye

gulsahgulec@gazi.edu.tr 


\section{GİRİŞ (INTRODUCTION)}

Harita mimarlık, şehircilik ve mühendislik gibi alanlarda yaygın olarak kullanılan bir temsil aracıdır. Mühendislik alanında genellikle donanımları ve sistemleri; şehircilik alanında kentsel akış ve ilişkileri; mimarlık alanında ise yapıları ve yapılaşma biçimlerini temsil eder. Bu alanlarda kullanılan haritalar görmeye alışı olduğumuz fiziki, coğrafi ya da siyasi haritalardan farklıdır. Mimarlık alanında kullanılan haritalar ise daha farklı bir temsil aracı olarak karşımıza çıkmaktadır. Bunlar tekniği ve estetiği birleştiren araçlardır. Mimarlıkta haritalar yalnızca bir temsil değil aynı zamanda bir tasarım aracı olarak kullanılmaktadır. Buna yaratıcı baritalama denir. Yaratıcı haritalama, haritaları mimarlığın başlıca temsil ve tasarım araçlarından biri haline getirmiştir. Hatta haritalar artık mimari tasarım sürecinin belirleyeni, parçası ve kendisi olarak görülmektedir (Alanyalı Aral, 2018, 1-6). Böylece mimarlıkta çoğu zaman bir temsil aracı olmaya indirgenen harita bir tasarım aracına dönüşmektedir. Harita ayrıca bir sorgulama aracıdır; sosyal, fiziksel, kültürel, ekonomik, politik ve teknolojik yapının sorgulanması için bir altlık oluşturmaktadır. Başka deyişle, yapısal çevre haritanın sorgulaması altındadır. Bu sorgulama boyunca haritanın amacı genellikle bir yerin ilişkiler ağını, olasılıklarını ve potansiyellerini ortaya koymaktır. Tasarım her zaman orada bir yerdedir. Harita, tasarımın ortaya çıkmasını sağlamaktadır (Tawa, 1998, 35-45).

Haritanın bir tasarım aracı olması onu farklı anlamlara ve okumalara açık hale getirmiştir. Bu durum haritanın belirsiz, değişken ya da göreceli bir araç olduğuna işaret etmektedir. Diğer yandan, kartografi; yani, haritacılık haritanın kesinlik içeren bilimsel bir temsil aracı olarak görülmesine yol açmıstır. Mimarlık gibi sanat ve bilim arakesitindeki bir alanda haritanın etkin ve yaygın bir temsil ve tasarım aracı olarak kullanılması ise bu araca olan bakış açısının değişmesini sağlamıştır. Yine de mimarlık alanında harita uzun yıllar boyunca iki boyutlu mekânsal bir temsil aracı olarak kullanılmıştır. Ancak zaman içerisinde haritanın üç boyutlu bir ilişkiler ağı olduğu anlaşılmıştır (Kitchin, Dodge, Perkins, 2011).

Bu anlayışın daha çok 19901 ylllarda bilgisayar teknolojilerinde yaşanan gelişmelerle birlikte ortaya çıktığ1 düşünülmektedir. Ancak harita mimarlık alanında 19601 yıllardan itibaren görünen ve görünmeyen ilişkilerin birlikte ele alınmasını sağlayan bir araç olmuştur. Hatta bu ilişkiler, harita sayesinde, yeni bir görünürlük kazanmıştır. Gelişmekte olan bilgisayar teknolojileri ise görünürlüğü farklı bir boyuta taşımışıı. Bunun nedeni, haritaların sanal gerçeklik boyutu olarak anılan yeni bir ortamda oluşturulmaya başlamıs olmasıdır. Bu ortam, mimarlıkta haritalama sürecinde olduğu kadar tasarlama sürecinde de önemli değişimlerin ortaya çıkmasını sağlamıştır. Öyle ki, harita ve 
tasarım arasındaki geleneksel temsiliyet ilişkileri bilgisayar destekli sanal ortamda değişime uğramış; bu ortamda oluşturulan harita, tasarımı temsil eden bir araç olmanın ötesine geçerek kendisini temsil etmeye başlamıştır. Böylece mimarlıkta haritanın yalnızca bir temsil aracı olmadığı bir kez daha ortaya çıkmıştır. Harita, tasarımın kendisidir; kendisini ve kendi gerçekliğini temsil etmektedir.

Temsiliyet ilişkilerinde yaşanan değişimler haritaları güncel bir tartışma konusu haline getirmektedir. Daha önce de belirtildiği gibi, mimarlıkta haritaların hem temsil hem de tasarım araçları olarak kullanılması yaratıcı haritalama olarak tanımlanmaktadır (Alanyalı Aral, 2018, 1-6). Bu makalede ise yaratıc haritalamanın haritanın temsil ve tasarım aracı olarak kullanıldığ1 bir süreç; yaratıcı haritanın ise bu sürecin sonunda ortaya çıkan bir araç olduğuna işaret edilmektedir. Mimarlık literatüründe yaratıcı haritalama süreci ya da eylemi üzerine yapılmış birçok tartışma bulunmaktadır. Son yıllarda bu tartışmalar, yaratıcı haritalama ile kentsel, mekânsal ve eylemsel ilişkilerin temsil edildiğini ve dahası bunların haritalar aracıllğıyla tasarlanabildiğini ortaya koymaktadır (Alanyalı Aral, 2019). Bununla birlikte, ne yaratıcı haritalama süreci ne de yaratıcı haritanın kendisi ilişki kurmakla ya da ilişkisel haritalarla sınırlı değildir. Yaratıcı haritalama, ilişkisel haritaların yanı sıra çok farklı kategoriler altında ele alınmaktadır. Öyle ki, bu süreç mekânsal akışı, oyunu ya da olayı, katmanlaşmayı ve ağ biçimli oluşumları temsil ettiği gerekçesiyle drift, game-board, layering ve rbizome başlıkları halinde tartışılmaktadır (Corner, 2011). Ancak makalede yaratıcı haritalar üzerine daha farklı ve kapsamlı bir tartışma ortaya koyulmaktadır. Yaratıcı haritalar, mimarlıkta öne çıkmış; yalnızca mimari temsil değil mimari tasarım alanında da fark yaratmıs olan zihinsel (mental), kuramsal (theoretical), anlatımsal (narrative), şekilsel (figurative), alg1sal (perceptional), imgesel (imaginal), işlevsel (funtional), dizinsel (indexical), ilişkisel (relational) ve etkileşimsel (interactional) haritalar başlıkları altında ele alınmaktadır. Bunlar makale kapsamında çeşitli harita örnekleri (Lynch, 1960; Jencks, 1973; Tschumi, 1976; Rowe, Koetter, 1978; Libeskind, 1979; Hadid, 1983; Koolhaas, 1991; MVRDV, 1999; Lynn, 2000 ve Foster, 2012) üzerinden tartışılmaktadır. Mimarlıkta haritanın aynı zamanda üç boyutlu bir tasarım aracı olduğunu ortaya koyan bu tartışmalar literatüre önemli bir katkı sağlayacaktır. Böylece haritayı iki boyutlu bir temsil aracı olmaya indirgeyen bakış açısının değişmesi gerektiği anlaşılacaktır.

\section{TEMSİL VE TASARIM ARAÇLARI OLARAK HARİTALAR (MAPS AS THE TOOLS OF REPRESENTATION AND DESIGN)}

Harita mimarlıkta genellikle bir temsil aracı olmaya indirgenmiştir. Ancak harita aynı zamanda bir tasarım aracıdır. Haritanın mimarlıkta bir temsil ve tasarım aracı olarak kullanılması tasarımı temsil etmesinin yanı sıra onu oluşturmasını sağlamaktadır. Son yıllarda mimari tasarımın oluşum sürecinde harita önemli bir rol oynamaktadır. Dahası haritalama bir tasarlama eylemi olarak ele alınmaktadır. Ayrıca haritalamanın fark etmeyi ve kaydetmeyi gerektirdiği belirtilmektedir. Buna göre, haritalama bir yeri fark etmek ve onu var eden ilişkileri, gerilimleri ve olasılıkları kaydetmektir. Bununla birlikte, harita potansiyelleri keşfetmeyi gerektirir. Böylece spekülatif bir araç haline gelir (Tawa, 1998, 35-45). Diğer yandan, haritanın yalnızca var olana işaret etmediği; yeni olanı inşa ettiği için performatif bir araç olduğu belirtilmiştir. Harita, geçmişe ve bugüne olduğu gibi geleceğe yönelik projeksiyonları da içerir. Bu durumda ise projektif bir araca dönüşmektedir (Corner, 2011). Dolayısıyla haritanın birçok farklı yönü ve rolü olduğu söylenebilir. Son yıllarda haritanın yaratıcı yönü dikkat çekmektedir. Harita yaratııı, yansıtıcı ve yorumlayıcı bir araç olarak kullanılmaktadır 
(Kitchin, Dodge, Perkins, 2011). Makalede ise haritanın bir temsil ve tasarım aracı olarak kullanıldığında yaratıcı hale geldiği savunulmaktadır.

\subsection{Yaratıc1 Haritalar (Creative Maps)}

Mimarlıkta bir temsil ve tasarım aracı olarak kullanılan yaratıcı haritalar, yere özgü görünen (somut) ve görünmeyen (soyut) özellikleri ortaya çıkarır. Hatta yaratıcı haritalar, geleneksel haritalardan farklı olarak, görünmeyene odaklanır. Yaratıcı haritalama süreciyle haritalar yerin gizli kalmış özelliklerini ve yere özgü değerleri tasarım sürecinin parçası haline getirir (Amoroso, 2012). Bu süreçte tasarım yerle bütünleşir ve/veya yeni bir yer tasarımı gerçekleştirilir. Bu nedenle, mimari tasarımda yaratıcı haritalara büyük bir ilgi gösterilmiştir. Son yıllarda bu ilgi, bilgisayar destekli teknolojilerin sağladığı yeni tasarlama ve haritalama ortamıyla ve olanaklarıyla birlikte dikkat çekici bir biçimde artmıştır. Bilgisayar teknolojileri, tasarımlara olduğu gibi, haritalara da yeni bir boyut kazandırmıştır. Bu teknolojiler sayesinde haritalar iki boyutlu ve statik olmaktan çıkmış; üç boyutlu ve dinamik araçlar olarak kullanılmıştır (Paez, 2019). Ancak bilgisayar teknolojilerinin gelişmesi ve yaygın bir kullanım ağı edinmesiyle ortaya çıktığı düşünülen yaratıcı haritaların mimarlık alanındaki kullanımı henüz bu teknolojilerin olmadığı yıllara uzanmaktadır. Daha önce de belirtildiği gibi, bu haritalar makale kapsamında zihinsel, kuramsal, anlatımsal, șekilsel, algısal, imgesel, işlevsel, dizinsel, iliskisel ve etkileşimsel haritalar başlıkları altında tartısılmaktadır.

\subsubsection{Zihinsel Haritalar (Mental Maps)}

Zihinsel haritalar genellikle kentsel ve mimari mekânı anlamak ve algıllamak için kullanılan haritalardır. Bu haritalar mekân hakkında bilgi sahibi olmayı sağlamaktadır. Bununla birlikte, haritalar genellikle mekânın yalnızca fiziksel değil zihinsel oluşumunun da bilinir ve görünür hale getirilmesini sağladığı için yaratıcı eylemler olarak tanımlanmıştır (Alanyalı Aral, 2018, 1-6). Bu tanıma göre, zihinsel haritaların yaratıcı haritalar olduğu ortaya çıkmaktadır. Zihinsel haritalar, mekânın öncelikle zihinde oluşmasını sağlamaktadır. Böylece kent gibi karmaşık bir mekân bile zihinsel haritalar aracılı̆̆ıla anlaşılabilir ve algılanabilir hale gelir (Buzan, 2006). Bununla birlikte, zihinsel haritalar yalnızca kenti ya da kent mekânını temsil eden araçlar değildir. Bunlar, kentsel ve mekânsal bir ilişkiler ağı önermektedir. Bu nedenle, kent ve mekân tasarımı için önemli araçlar olarak görülmektedir.

Mimarlıkta bu haritalar, Lynch'in 1960 yıllnda ortaya koyduğu zihin haritalarıyla özdeşleştirilmiştir. Bunlar yollar, kenarlar, bölgeler, işaret ve dügüm noktaları olmak üzere Lynch tarafindan tanımlanan çeşitli kentsel elemanlarla oluşturulmuştur (Resim 1). Bu elemanlar kentleri, yapılaşma biçimlerini ve zihinde oluşan kent imgesini anlamak için ortaya koyulmuştur (Lynch, 1960). Ancak zihinsel haritalar, kentsel bir okuma yapma ya da kenti anlama araçları olmanın ötesindedir. Bugün de mimarlık alanında birçok zihinsel harita örneği geliştirilmektedir. Bu haritalar, mimari tasarımların kentsel elemanlarla ve kent mekânıyla ilişkilendirilmesini; bu ilişkilere göre kent içerisinde kendi yerini edinmesini sağlamaktadır. 


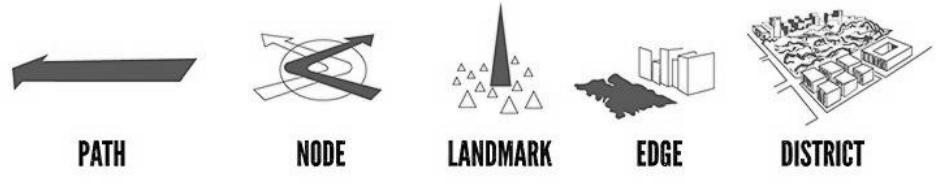

Resim 1. Mental map, Kevin Lynch, 1960 (parempimaailma.net)

\subsubsection{Kuramsal Haritalar (Theoretical Maps)}

Kuramsal haritaların mimarlık alanında kuramla sınırlı olduğu düşünülmektedir. Oysa bunlar, kuramsal ve tasarımsal bilginin bir araya getirildiği ve ilişkilendirildiği haritalar olma özelliğine sahiptir. Bilginin haritalanması, birçok disipliner alanda olduğu gibi, mimarlık alanında da oldukça önemlidir. Hatta mimarlıkta harita, mekânsal bilginin iki boyutlu bir düzlemine aktarılması olarak görülmektedir. Haritalama da bu düzlemin üzerine başka bir bilginin işlenmesidir. Dolayısıyla harita, grafik bir ürün olmanın ötesindedir. Bilgiyi ve bunlar arasında kurulan ilişkiyi içermektedir (Acar, 2019, 19-25). Mimarlığın bilgi alanını ise nesnel ve öznel, gerçek ve sanal, somut ve soyut ya da yerel ve evrensel gibi birbirine karşıt olduğu düşünülen; ancak birbiriyle ilişkilenen çok sayıda bilgi oluşturmaktadır. Mimarlık disiplinerarası bir bilgi alanıdır. Kuramsal haritalar ise mimarlığın bilgi alanını haritalamak için kullanılır. Bunun için, bilginin bir araya getirilmesini ve ilişkilendirilmesini sağlamaktadır (Corner, 2011, 89-101). Bu ilişkiler, haritalanan bilginin görselleştirilmesine olanak tanımaktadır. Böylece kuramsal haritalar, bilgilendirme ve görselleştirme araçları haline gelir. Haritalanan şey hakkında görsel bilgi verir. Dahası kuramsal haritaların bilgiyi inşa ettiği belirtilir (Kitchin ve Dodge, 2007, 331-344). Jencks'in ilk kez 1973 yllında ortaya koyduğu haritalar, mimarlık alanının en bilinen kuramsal harita örneklerinden biridir (Resim 2).

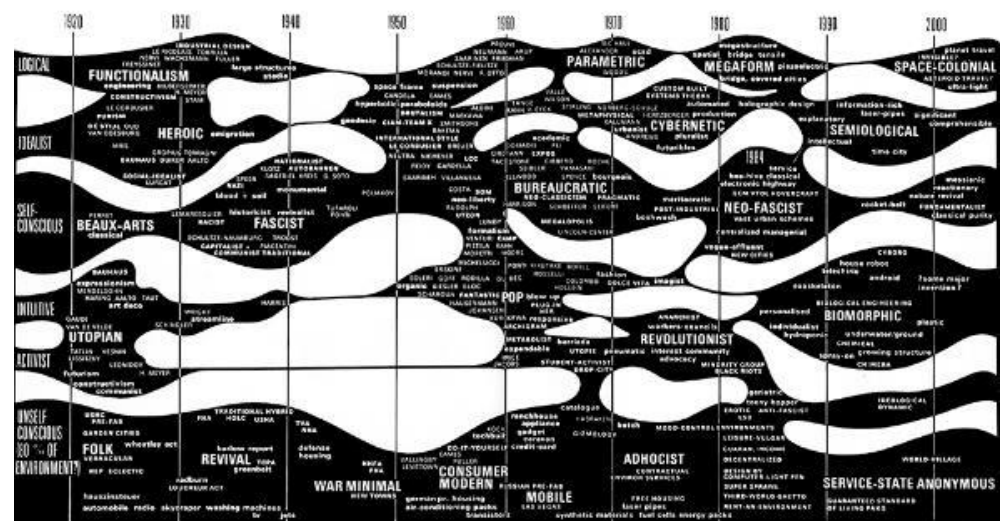

Resim 2. Evolutionary tree, Charles Jencks, 1973 (harvarddesignmagazine.org)

Jencks, bu haritalarda çeşitli kavramları, akımları, dönemleri, mimarları ve tasarımları bir araya getirmiştir. Bunları aralarında çok çeşitli ilişkiler olduğunu gösterecek şekilde haritalamıştır (Jencks, 2000). Sonraki yıllarda farklı versiyonlarını üreterek bu haritaları çoğaltmıştır. Bunlar eleştirel 
mimarlık kuramının temelini oluşturan haritalardır. Bugüne kadar birçok eleştirmen, kuramcı ve tasarımcı bu haritaları kullanarak mimarlı̆̆ın bilgi alanına katkı sağlamıştır. Bu nedenle, kuramsal haritalar genellikle mimarlık kuramıyla sınırlandırılmıştır. Ancak bu haritalar aynı zamanda mimarlığın tasarım alanıyla ilgilidir. Öyle ki, mimari tasarımların kavramsal ve biçimsel olarak geliştirilmesine etki etmiştir. Başka deyişle, kuramsal haritalar tasarımların çeşitli kavramlara, yaklaşımlara ve akımlara göre biçimlendirilmesini sağlamış ya da bunlara göre biçimlendirildiğini açığa çıkarmıştır. Böylece mimari tasarımları hem geliştirmiş hem de gerekçelendirmiştir. $\mathrm{Bu}$, mimarlıkta tasarım bilgisinin ve becerisinin de gelişmesi demektir.

\subsubsection{Anlatımsal Haritalar (Narrative Maps)}

Anlatımsal haritalar, kuramsal haritalarda olduğu gibi, mimarlık bilgisinin haritalanmasını gerektirir. Bunu yine bilginin görselleştirilmesini sağlayarak yerine getirir. Ancak bu haritalar, kuramsal haritalardan farklı olarak, görsel bilgiyi bir anlatıya dayandırır. Zaten harita, kendine özgü kavramlara sahip olması, kendi sözdizimi olan semboller sistemini kullanması ve yazıya benzer biçimde bilgi aktarabilmesi nedeniyle bir anlatıdır (Derrida, 1981). Haritanın bir anlatı olması, haritalanan şeyin bir olay kurgusu olduğuna işaret eder. Bu kurgu içerisinde bir ya da birden çok anlatı vardır. Anlatılar genellikle birbiriyle ilişkili olarak ele alınır. Böylece anlatımsal haritalar ortaya çıkar. Bu haritalar, mimarlıkta anlatımsal tasarımlar ortaya koymak için birer araç olarak kullanılmaktadır. Dolayısıyla yaratıcı haritalar arasında yer alır. Tschumi'nin 1976 yılında ortaya koyduğu Manhattan Transcripts adlı haritalar, mimarlık alanında öne çıkan anlatımsal harita örnekleri arasındadır (Resim 3).

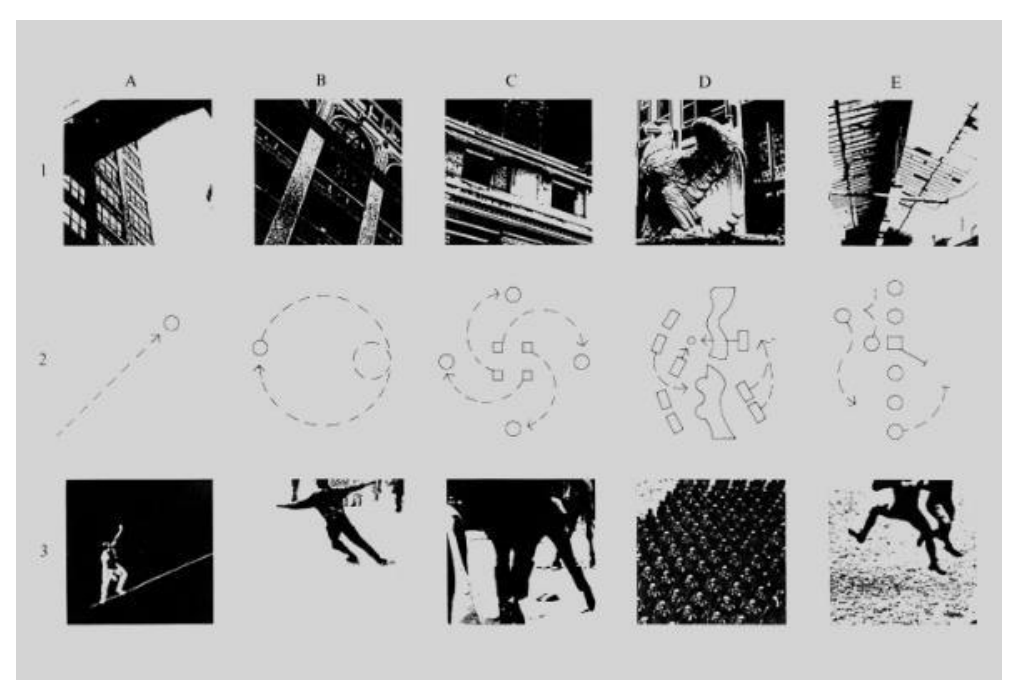

Resim 3. Manhattan Transcrips, Bernard Tschumi, 1976 (tschumi.com)

Tschumi, bu haritalarda büyüklük, yükseklik, karmaşıklık ve hareketlilik gibi kavramlarla çeşitli olaylar kurgulamıştır. Bunlar, Manhattan’a özgü kavramlar ve olaylardır (Tschumi, 2001, 58-109). Böylece kurgusal bir anlatım geliştirmiş; bunu Manhattan Transcripts adını verdiği o yere özgü 
haritalarla göstermiştir. Ancak anlatımsal haritalar yalnızca bir gösterim ya da temsil aracı değildir. Aynı zamanda bir tasarım aracı olarak geliştirilmiştir. Tasarımın bir olay kurgusuna; yani, bir anlatıma göre kavramsallaştırılmasına ve biçimselleştirilmesine aracılık etmiştir.

\subsection{4. Şekilsel Haritalar (Figurative or Figure-Ground Maps)}

Şekilsel haritalar, kentin şekil ve zemin ilişkileri üzerinden haritalanmasıyla ortaya çıkmıştır. Bu haritalarda genellikle kentin dolu alanları şekil olarak ve siyah renkle; boş alanları ise zemin olarak ve beyaz renkle gösterilir. Bu gösterim biçimi, kentsel mekânın doluluk ve boşluk oranlarının ortaya koyulması için geliştirilmiştir. Böylece yeni bir mekân tasarımının şekil ve zemin ya da doluluk ve boşluk ilişkilerine ve oranlarına göre yapılması öngörülmektedir. Şekilsel haritalar her ne kadar bu haliyle şekle; yani, kenti oluşturan mimarlık nesnelerine odaklanmış gibi görünse de bunlar aslında daha çok kentsel boşlukları ortaya koymayı, hatta bunları arttırmayı hedeflemektedir. Bu açıdan, kent mekânını ve onu oluşturan dolulukları ve boşlukları temsil etmenin ötesine geçmiştir. Bu haritalar, kentsel ve mimari ölçekte boşluklu tasarımlar geliştirilmesi için birer altlık olma görevi edinmiştir. Mekânın bir boşluk tasarımı olarak düşünülmesini ve kentin de benzer bir tasarım düşüncesiyle yeniden ele alınmasını gerektirmiştir. Bu yüzden, yaratıcı haritalardır; kenti ve kent mekânını temsil etme biçimiyle kentin mekânsal bir boşluk olarak tasarlanmasına katkıda bulunmaktadır. Bu haritalar, mimarlık ve şehircilik alanında daha çok Rowe ve Koetter'ın 1978 yılında ortaya koyduğu şekil ve zemin haritalarıyla birlikte ele alınmaktadır (Resim 4).

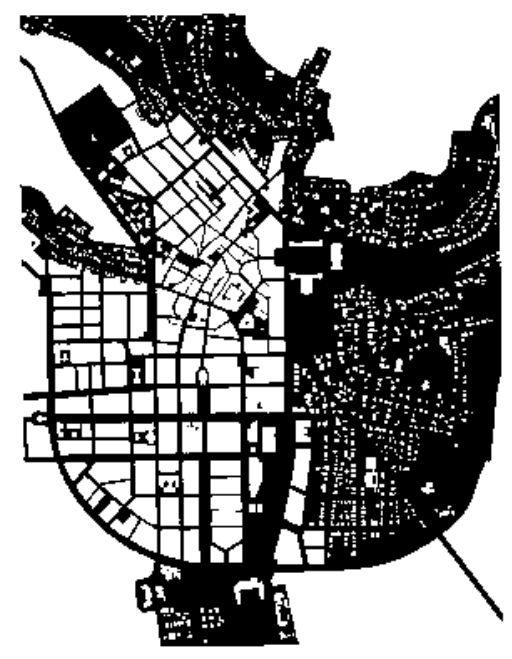

Resim 4. Figure-ground plan, Colin Rowe, Fred Koetter, 1978 (medium.com)

Rowe ve Koetter, bu haritalarla geleneksel şekil ve zemin ilişkilerinin tersine çevrilebileceğini göstermiştir. Şekil ve zemin haritalarının yaratıcı yönlerinden biri de budur. Bu yönüyle haritalar, bir kentte bulunan ve şekil olarak siyah renkle gösterilen binaların zemin olarak beyaz renkle de gösterilebileceğini ortaya koymuştur. Yani, binalar doluluk değil boşluk olarak da görülebilir (Rowe, 1978). Bu durumda, kentsel boşluk ve doluluk ilişkileri değişmektedir. Şekil ve zemin haritalarına bakarken siyaha; yani, şekle ya da doluluğa odaklanan bakışlar bu defa beyaz yerine siyahla gösterilen 
zemine ya da boşluğa çevrilir. Boşluk da doluluk gibi kesin ve açık bir biçimde görünür hale gelir. Böylece mimarların ve şehir plancılarının çoğu zaman dikkatinden kaçan boşluk, kentsel ve mekânsal boşluk olarak ortaya çıkar. Bunu görünür kılan ve ortaya çıkaran şekil ve zemin haritalarıdır. Bu haritalar, boşluğun tasarım sürecinin ve tasarımın kendisinin bir parçası olmasını sağlamaktadır. Kentsel ve mekânsal bir temsil aracı olmanın yanı sıra mekânın boşluk olarak tasarlanmasını sağlayan bir araç olarak kullanılmaktadır.

\subsubsection{Alg1sal Haritalar (Perceptional Maps)}

Algısal haritalar, mekâna yönelik algının ve tasarım anlayışının değişmesine neden olan haritalardır. Bunlar mekânsal boşluk, derinlik, düzensizlik, sıkışıklık ya da karmaşıklık algısı yaratarak mekânın bu algısal özelliklere göre tasarlanmasını sağlamaktadır. Bu özellikler, algısal haritalarda genellikle zamansız ve yersiz bir mekân anlayışının olduğunu ortaya koymaktadır. Dahası, algısal haritaların mekân anlayışı mekânın ötesinde düşünmeyi gerektirmektedir. Bu haritalar, mekânın dört duvarla ve tavanla sınırlı bir boşluk olmadığını göstermiştir. Hatta mekânın belirli bir ölçeğinin, merkezinin ya da işlevinin bulunmadığına işaret etmiştir. Dolayısıyla algısal haritalar, geleneksel mekân algısını değiştirmiştir. Bu değişim, mekân tasarımının da değiştiğini ya da değişmesi gerektiğini düşündürmektedir. Libeskind'in 1979 yllında yapmış olduğu mekânsal çizimler, bu düşünceyi örneklemektedir. Ancak bunlar daha çok olası mekânların ya da mekânsal olasılıkların çizildiği haritalar olarak görülmelidir (Resim 5).

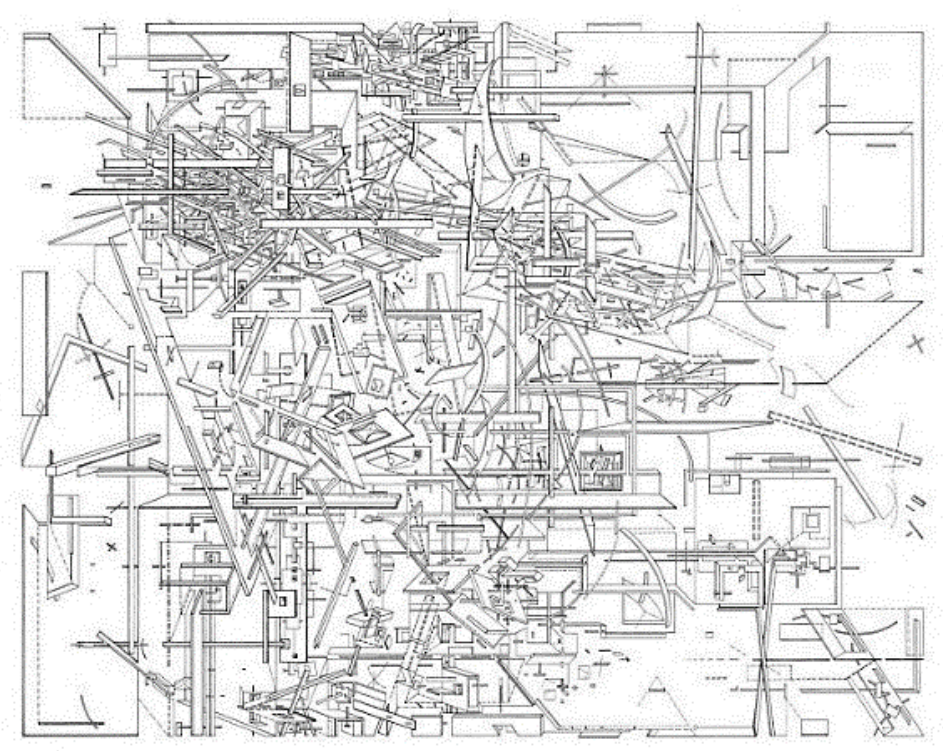

Resim 5. Micromegas, Daniel Libeskind, 1979 (socks-studio.com)

Libeskind bu haritalarda düşey, yatay ya da açılı olarak konumlandırılmış çizgisel, yüzeysel ve hacimsel elemanlarla ölçekler arası bir mekân arayışına girişmiştir. Mekânın gerçek ya da hayali olması önemli değildir. Önemli olan, bu haritaların hayal gücünü geliştirmesidir. Algısal haritalar, Libeskind'in çizimlerinde de olduğu gibi, hayal gücünü harekete geçirmektedir. Öyle ki, aynı harita 
birçok olası mekânı ifade edebilmektedir. Olasılık, belirsizlik, değişkenlik ve görecelilik bu haritaların başlıca özellikleridir (Kipnis, 2001). Bu özellikler, algısal haritaların mekâna yönelik yeni ve çok çeşitli algılamalara açık olduğunu göstermektedir. Başka deyişle, bu haritalar yeni mekânsal algiların oluşturulmasına aracılık etmektedir. Böylece mekâna dair bildiklerimizden; yani, hafıza ve deneyimden hareketle ve elbette hayal gücünün etkisiyle yeni mekânlar tasarlamayı mümkün hale getirmektedir.

\subsubsection{Imgesel Haritalar (Imaginal Maps)}

İmgesel haritalar, algısal haritalardan ayrışarak mekâna yönelik yeni, farklı ya da olası bir alg1 oluşturmak yerine daha çok yeni bir mekânsal imge ortaya koymak üzere geliştirilmektedir. Ancak bu haritalarda da hayal gücünün etkili olduğu görülmektedir. İmgesel haritalar, hayal gücüyle kâğgt üstünde olsa bile yeni bir gerçekliğin inşa edilmesini sağlamaktadır. Burada kastedilen imgenin inşasıdır. Ancak bilgisayar teknolojileri zaman içerisinde nesnenin ve onun temsili olan imgesinin birbirinden ayırt edilememesine; hatta imgenin nesneden daha gerçekmiş gibi görünmesine yol açmıştır (Baudrillard, 1988, 166-184). Buna bağlı olarak, gerçeklik ve temsiliyet ilişkisi değişime uğramıştır. Harita ise gerçek (fact) ve kurgu (fiction) olanı birbirinden ayırt edilemeyecek şekilde temsil etmeye başlamıştır (Corner, 2011, 89-101). Gerçeklik ve temsiliyet ilişkisinin değişmesi bu ilişkinin bozulduğunun göstergesi olarak yorumlanmıştır. Mimarlıkta dekonstrüktivizm olarak adlandirlan bozulma haritanın da geleneksel yapisinin bozulmasina (deconstruction of the map) neden olmuştur. Haritanın yapı bozumu ise alternatif arayışı olarak görülmüştür. Harita yazılar, işaretler ve imgelerden oluşur. Bunlar arasında kurulan ilişkilerin bozulması alternatif ilişkilerin oluşmasını sağlamıştır (Harley, 1989, 1-20). Böylece yeni bir gerçeklik anlayışını temsil eden imgesel haritalar ortaya çıkmıştır. İmgesel haritalar, kesin ve değişmez gerçekliğin temsili değildir. Bunlar belirsiz, göreceli ve değişken gerçeklikleri temsil etmektedir. Yeniliği ve yaratıcıllı̆ıı, yeni bir gerçekliğin temsil edilmesini ve tasarlanmasını sağlayacak imgeleri ortaya koymuş olmasından ileri gelir. Hadid'in 1983 yılında yaptığı dekonstrüktivist çizimleri mimarlık alanındaki imgesel harita örneklerindendir (Resim $6)$.

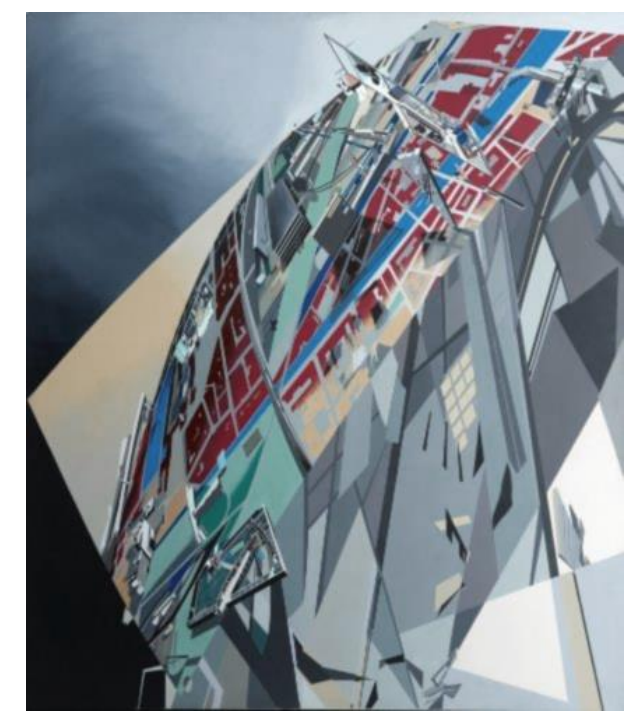

Resim 6. The World 89 Degrees, Zaha Hadid, 1983 (archdaily.com) 
Hayal gücünün ve yaratıcılığın örnekleri olan bu haritalar, Hadid’in yeni gerçeklik anlayışını temsil etmektedir. Bunlar, aynı zamanda, yeni bir mimarlık ve yeni bir mekânsallık anlayışının temsilleridir. Böylece çizimin ötesine geçmiş; harita olma özelliğini edinmiştir. Woods, bu haritalarla gökle yer, ufukla zemin, yapayla doğal arasındaki ilişkileri yöneten yeni bir mekânsal düzen geliştirildiğini belirtmiştir (Woods, 2008). Yeni düzen, temsili (soyut) ve gerçek (somut) olanın birlikte ve birbirinden ayırt edilemeyecek şekilde haritalanmasıyla ortaya çıkmıştır. Bu yaratıcı bir haritalamadır. Hem haritacılığın hem de mimarlığın geleneksel yapısını bozarak yeni bir imge ortaya koymaktadır. Bu imge, kentsel ve mimari tasarım anlayışını değiştirmekte ya da değiştirmeyi önermektedir. Bu nedenle, imgesel haritalar birer kent ve mimarlık temsili olmanın ötesindedir.

\subsection{7. İşlevsel Haritalar (Functional Maps)}

İşlevsel haritalar, mimarlıkta işlevin ve işlevsel ilişkilerin ortaya koyulduğu haritalardır. Mimarlıkta işlev kalıcı ve değişmez değildir. Geçici ve değişken işlevlerden de söz edilebilir. Geçicilik, değişkenlik ya da belirsizlik bir mimari tasarımın işlevsel özellikleri olabilir. Böyle olunca, işlevsel haritalar işlevler arasındaki geçici, değişken ya da belirsiz ilişkilerin haritalanmasını sağlar. $\mathrm{Bu}$ haritalar aracılı̆̆ıla yeni işlevsel ve mekânsal ilişkiler ortaya çıkar. Dolayısıyla işlevsel haritalar, temsil aracı olmanın yanı sıra tasarım aracı olarak da kullanılır. Koolhaas'ın 1991 yılında tasarladığ1 Yokohama kent planı işlevsel bir haritadır (Resim 7). Programmatic lava olarak adlandırılan bu haritada parklar, tiyatrolar, sinemalar, restoranlar, spor salonları, sergiler, mağazalar ve bir kentte olabilecek birçok kamusal işlev birlikte ve iç içe yer alır (Office for Metropolitan Architecture, 1991). İşlevsel ilişkilerin sürekliliği ve yeni ilişkiler oluşturma potansiyeli haritanın kentsel ve mekânsal bir tasarım aracı olmasını sağlamıştır. Ayrıca bu haritanın Jencks'in 70li yıllarda ortaya koymuş olduğu kuramsal haritalara olan benzerliği dikkat çekicidir. Jencks'in kuramsal haritaları gibi, Koolhaas'ın işlevsel haritaları da haritalanan öğelerin sürekli ve ilişkili olduğunu göstermektedir.

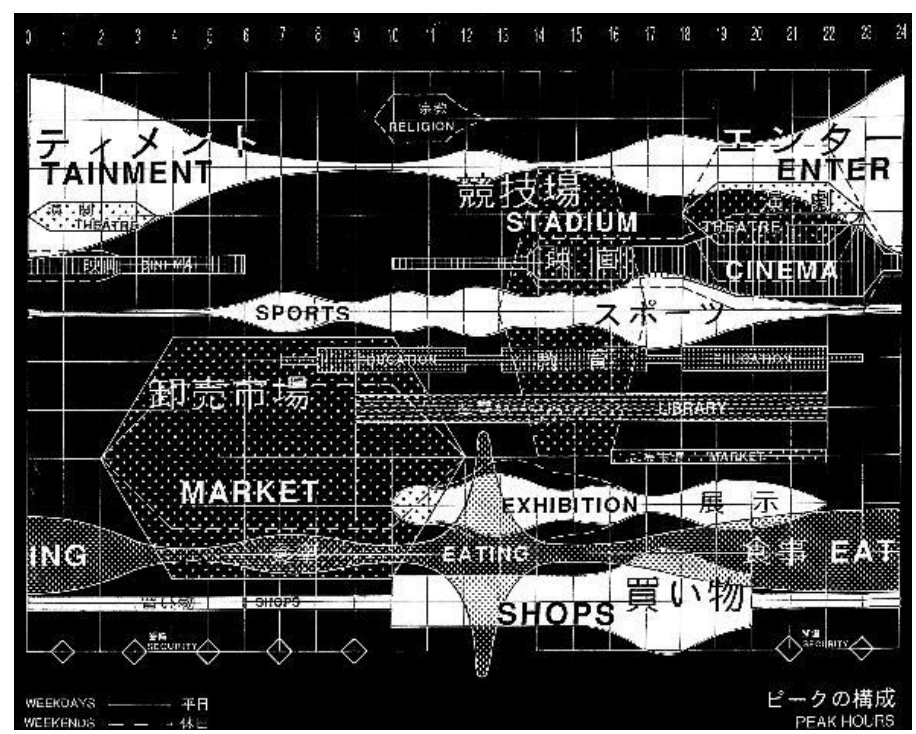

Resim 7. Yokohama Programmatic Lava, Rem Koolhaas, 1991 (oma.eu) 


\subsubsection{Dizinsel Haritalar (Indexical Maps)}

Dizinsel haritalar işlevsel, biçimsel, kentsel ya da mekânsal ilişkilerin bilgisayar teknolojileri kullanılarak bir dizi veri halinde işlenmesiyle ortaya çıkmaktadır. Mimarlıkta dizinsellik, 20. yüzyılın sonunda bilgisayar teknolojilerinin yönlendirdiği, dahası yönettiği tasarım sürecini tanımlamak için kullanılmıştır (Dean, 2007). Dizinsel haritalar ise bu süreçte dizinlenen verilerle oluşturulmaktadır. Bugün bu haritalarda 21. yüzyılın bilgisayar teknolojileri kullanılarak işlenen veriler, sekans; yani, dizilim oluşturulmasını sağlamaktadır. Bu daha çok işlevsel ve mekânsal bir dizilimdir. Mimari tasarım sürecinde farklı işlevler ve mekânlar bir sekans oluşturacak biçimde art arda getirilmektedir. $\mathrm{Bu}$ nedenle, dizinsellik (indexicality) aynı zamanda ardışılık (sequentiality) olarak da tanımlanır (Baudrillard, Nouvel, 2011). Mimarlıkta kullanılan dizinsel haritalar genellikle ardışık işlevsel ve mekânsal ilişkileri ortaya koymaktadır.

Bunların en iyi bilinen örneklerinden biri MVRDV'nin 1999 yılında insana, mekâna ve kente dair çok sayıda veri hareketini ve akışını düzenlediği ve dizinlediği haritalardır (Resim 8). Bu haritalar, hareketli ve akışkan bir kent imgesinin ortaya çıkmasını sağlamıştır. Kent imgesi bütünüyle verilerden oluşmaktadır (MVRDV, 1999). Bu yalnızca geleceğin değil aynı zamanda bugünün kentidir. Kentin bilgisayar destekli bir ortamda dizinlenen verilerle oluştuğunun göstergesidir. Dizinsel oluşum sürecinde haritalar önemli bir rol üstlenmiştir. Kentin mimarisi ve nihayetinde imgesi bu haritalarla karakterize edilmiştir. Kentin en karakteristik özelliği ise dizinselliğidir. Böylece, 20. yüzyllın sonuna gelindiğinde, kentsel ve mimari tasarımın bilgisayar teknolojileriyle oluşturulan dizinsel bir hareketlilik, akışkanlık ve canlılık özelliği edindiği görülmektedir.

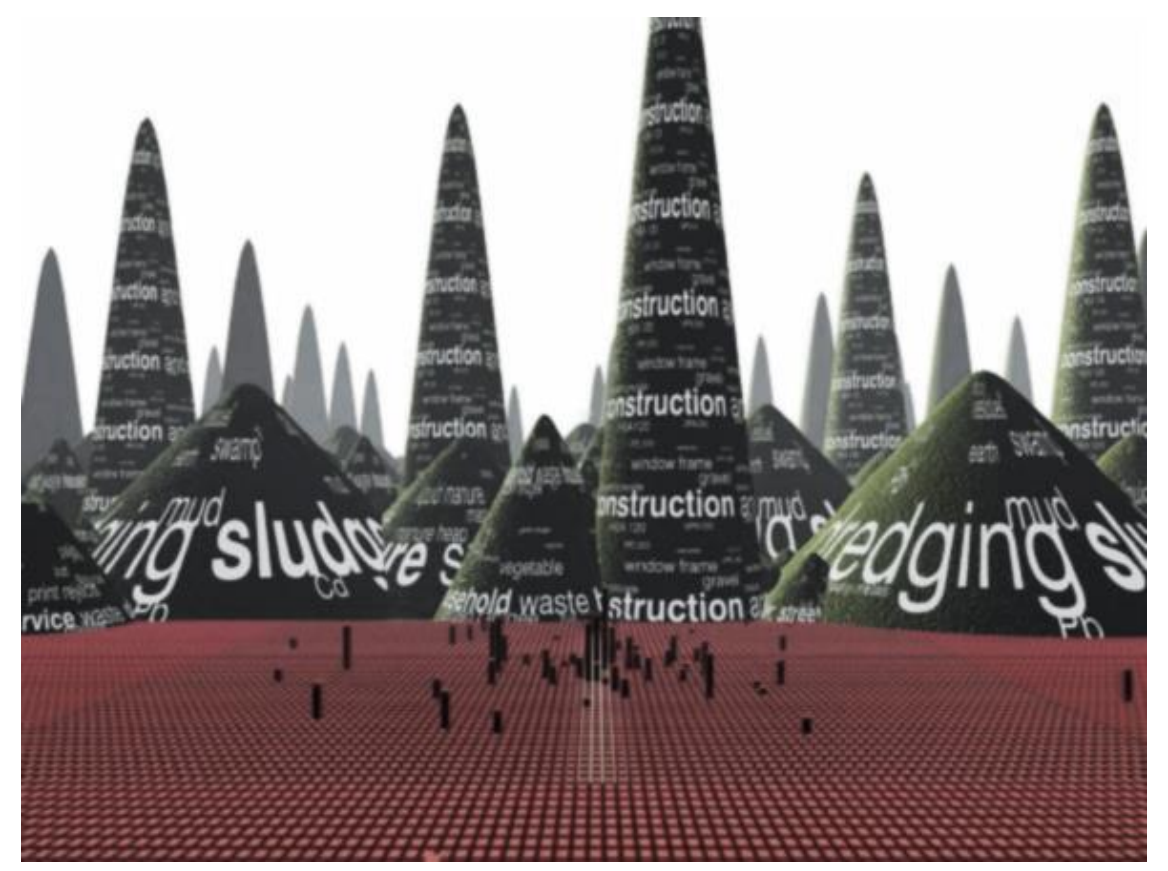

Resim 8. Datatown, MVRDV, 1999 (mvrdv.nl) 


\subsubsection{Illiskisel Haritalar (Relational Maps)}

İlişkisel haritalar, 21. yüzyılın başında, kentsel ve mimari tasarımda yeni bir canlıllğın oluştuğuna işaret etmiştir. Canlılık artık bilgisayar ortamında oluşan ve tasarımın canlı biçimini oluşturan ilişkiler aracıllğı̆la edinilmektedir. Yine de ilişkisel haritalar biçimden ya da üründen (product) çok sürecin (process) tasarlanmasını gerektirmiştir. Bu bilgisayar destekli bir tasarım sürecidir. Bu süreçte bilgisayar teknolojileriyle işlevsel, biçimsel ya da bağlamsal ilişkiler tasarlanmaktadır. Hatta mimari tasarım bu sürecin sonunda ve tasarlanan ilişkiler doğrultusunda neredeyse kendiliğinden ortaya çıkmaktadır. Dolayısıyla son yıllarda mimarlıkta canlılık (animism), dizinsellik (indexicality) ve ilişkisellik (relationality) gibi kavramların yanı sıra kendiliğindenlik (spontaneity) kavramı da öne çıkmıştır. Mimarlığın kendi kendisini oluşturduğu iddiası (the autopoeisis of architecture) ortaya atılmıştır (Schumacher, 2011).

Tasarım ya da oluşum sürecinde ilişkisel haritaların önemli bir rolü bulunmaktadır. Mimari tasarım, haritalanan verilere ve bunlar arasında kurulan ilişkilere göre oluşmaktadır. Haritalama ise geleneksel haritalarda bir aradalığı mümkün olmayan veri çeşitliliği ile bu verilerin yerle ve birbiriyle ilişkilerini ortaya koyan ilişkisel bir eylem halini almaktadır (Alanyalı Aral, 2019, 1-2). Diğer yandan, tüm haritalama eylemleri aslında ilişkiseldir. Harita, ilişkisel; yani, rizomatik bir oluşum olarak değerlendirilmektedir. Rizom, ilişkisel olmayı; kavramlar ve bağlamlar arasında yeni ve çok çeşitli ilişkiler kurmayı ifade etmektedir. Rizomatik ise ağ biçimli ilişkisel bir oluşum demektir. Rizomatik bir oluşum olarak tanımlanan harita, çoklu ve açık uçlu olmayı gerektirmektedir. Çokluluk ve açık uçluluk, haritayı karmaşık bir ilişkiler ağı haline getirmektedir. Bu nedenle, haritanın aynı biçimde yeniden üretilmesi oldukça zor hale gelir. Haritanın yaratıcıllğı bu noktada ortaya çıkar. Yeniden üretilememesi haritayı yaratıc1 kılar (Deleuze ve Guattari, 2005).

Yaratıcı bir harita olan ilişkisel harita genellikle bir yerin ya da bir nesnenin ilişkiler ağını, olasılıklarını ve potansiyellerini ortaya koymak için kullanılmaktadır (Tawa, 1998, 35-45). Buradan ilişkisel haritaların potansiyel ilişkileri temsil ettiği anlaşılmaktadır. Ancak mimarlıkta kullanılan ilişkisel haritalar, bu ilişkileri temsil etmekle kalmayıp; onları tasarımı oluşturan verilere dönüştürdügünnde yaratıcı hale gelir. Lynn’in 2000 yılında tasarladığı embriyolojik evlerin haritaları mimarlık alanında kullanılan ilişkisel haritaları örneklemektedir (Resim 9). Bu haritalar, evlerin biçimlerini ya da Lynn'in ifadesiyle morfolojilerini oluşturan dijital veriler arasında değişken ilişkilerin kurulmasıyla ortaya çıkmıştır. İlişkilerin değişmesi, evlerin de morfolojik olarak değişmesini sağlamıştır. Bunlar hareketli, dinamik ve canlı morfolojilerdir. Bu nedenle Lynn, biyolojik olduklarını belirtir (Lynn, 2013, 125-130). 


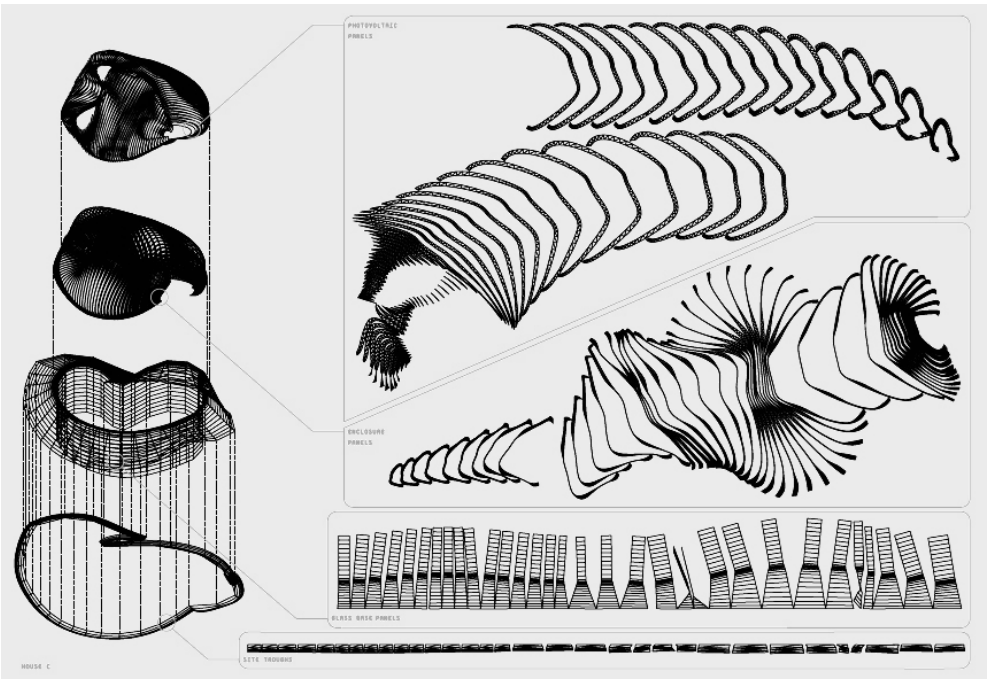

Resim 9. Embryologic Houses, Greg Lynn, 2000 (Carpo, 2013)

Mimarlıkta bu morfolojiler, blob olarak adlandirilan; dahası, blob mimarisi (blob architecture ya da blobitecture) olarak anılan yeni bir mimarlık akımının gündeme gelmesine neden olmuştur. Kare, dikdörtgen ya da küre gibi bilinen bir geometrik biçime uymayan bloblar, bilgisayarların dizinlediği veriler arasında değişken ve devingen ilişkilerin kurulmasıyla oluşmuştur. İlişkisel haritalar ise mimari biçimin bu ilişkilere göre oluşmasını sağladığı için yalnızca bir temsil değil aynı zamanda bir tasarım aracı olarak kullanılmıştır.

\subsubsection{Etkileşimsel Haritalar (Interactional Maps)}

Etkileşimsel haritalar son yıllarda mimarlıkta kullanılan en etkili temsil ve tasarım araçları arasındadır. Bunlar ilişkisel olmanın ötesine geçtiği için etkileşimsel olarak adlandırılmaktadır. Etkileşimsel haritalar, mimari ya da kentsel bir tasarımın görünen ve görünmeyen ilişkilere göre oluşmasını sağlamakla kalmayıp; bu ilişkilerin değişmesine, tasarımın ise değişen ilişkilere göre yeniden şekillenmesine neden olmaktadır. Dolayısıyla etkileşimsel haritalar, değişkenlik ve devingenlik üzerine kuruludur. Tasarımı oluşturan ilişkileri ve tasarımın kendisini yeniden oluşturur. Yeniden oluşum sürecinde kentsel, mekânsal, toplumsal, kültürel ya da kamusal birçok ilişki etkili olmaktadır. Etkileşimsel haritalar tüm bu ilişkileri iki ya da üç boyutlu çizimlerle ve görüntülerle ortaya koymaktadır. Etkileşimsel haritaları oluşturan görüntülerin hareketli ve değişken olması bu haritaların etkisini arttırmaktadır. Foster'ın 2012 ylında Venedik Mimarlık Bienali kapsamında sergilediği enstalasyon, hareketli görüntüleri ve görüntülere eşlik eden etkileyici sesleriyle üç boyutlu bir etkileşimsel harita örneği olarak karşımıza çıkmaktadır (Resim 10). 

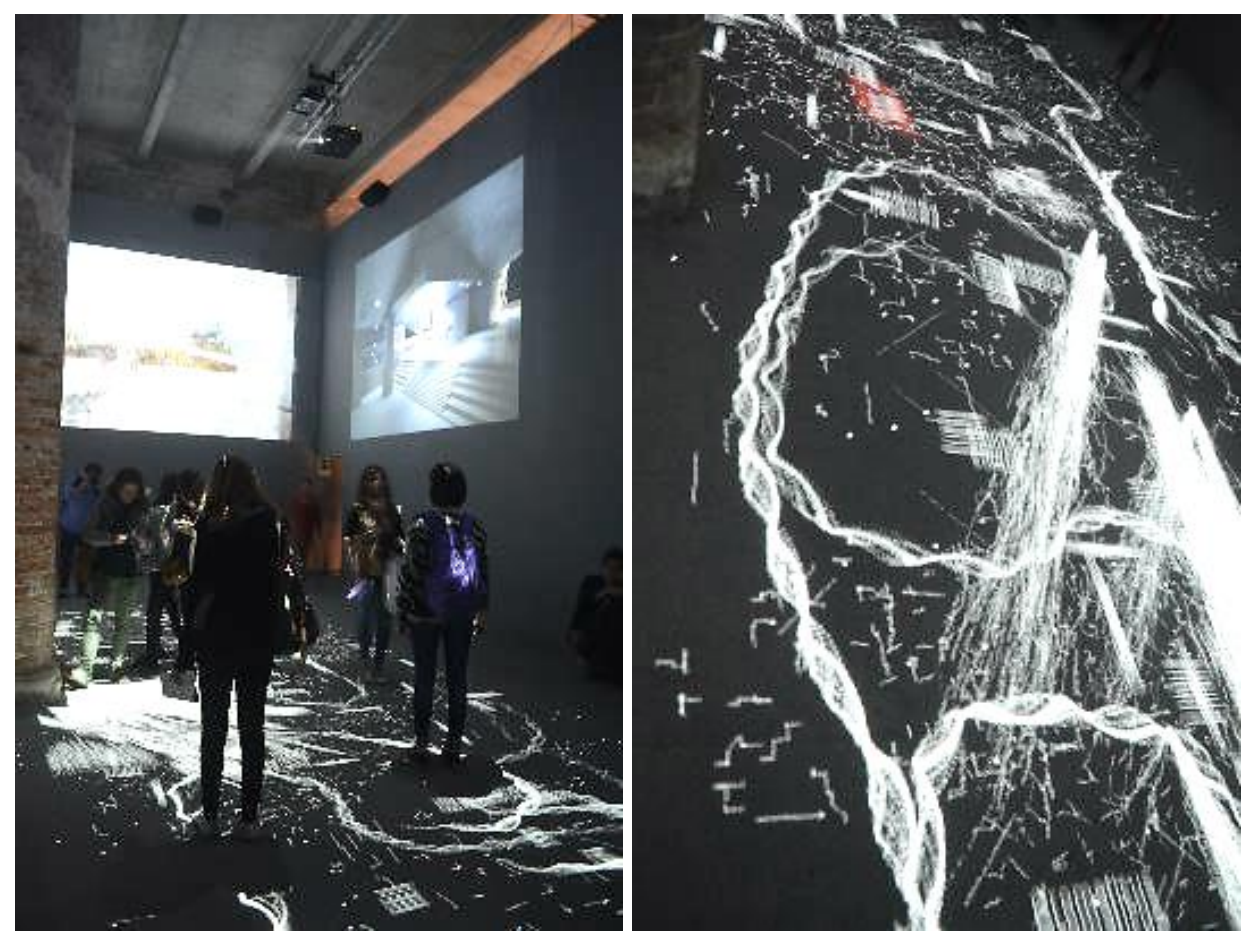

Resim 10. Gateway, Norman Foster Architects, 13th Venice Architecture Biennale, 2012 (Yazarın kişisel fotoğraf arşivinden)

Foster, bu enstalasyonu iki boyutlu görüntülerle bir sergi mekânının içerisinde üç boyutlu bir harita olarak tasarlamıştır. Harita, antik çağlardan bugüne kentlerin, mimarlığın ve genel olarak insanlığın geçirdiği değişimi ortaya koyan hareketli görüntülerden oluşmaktadır. Ziyaretçiler, görüntüleri algilamaya ve birbirleri arasında ilişki kurmaya çalışırken ses ve video enstalasyonu olarak tasarlanan bu üç boyutlu harita sürekli olarak değişmektedir. Haritanın etkileşimsel olarak değerlendirilmesinin nedeni, sesler ve görüntüler değiştikçe bunların ziyaretçilerin algısını değiştiriyor olmasıdır. Foster, bunu etkileşimsel bir değişim olarak yorumlamıştır. Tasarladığı enstalasyonda farklı yerlere ve zamanlara özgü kamusal mekânların görüntülerini kullanmıştır. Foster’a göre kamusal mekânlar, bienalin dönem teması olan Ortak Zemin'i (Common Ground) oluşturmaktadır (Saieh, 2012). İnsanlar, kamusal mekânları ortak olarak kullanmaktadır. Bu mekânlar, insanları bir araya getirmekte ve buluşturmaktadır. Foster'n etkileşimsel haritası, dünyanın belli başlı kamusal mekânlarını ziyaretçilere göstermenin; yani, bunları temsil etmenin yanı sıra bu mekânlar arasında algısal ilişkilerin kurulmasını sağlamıştır. Etkileşimsel haritaların genellikle hareketli ve değişken görüntülerle ortaya koyduğu bu ilişkiler yeni kentsel, mekânsal ve kamusal ilişkilerin ve etkileşimlerin kurulması için bir altlık oluşturmaktadır.

\section{TARTIŞMA VE SONUÇ (DISCUSSION AND CONCLUSION)}

Mimarlıkta haritalar genellikle temsil araçları olarak kullanılır. Ancak haritaları aynı zamanda tasarım araçları ve altlıkları olarak görmek ve kullanmak gerekir. Bu makalede hem temsil hem de tasarım aracı olarak kullanılan haritalar yaratıc haritalar olarak tanımlanmıştır. 1960lı yıllardan bu yana mimarlıkta kullanılan yaratıcı haritaların temsil ve tasarım araçları olduğuna işaret edilmiştir. Buna 
karşılık, haritalar 199011 yıllara kadar çoğunlukla iki boyutlu bir temsil aracı olmaya indirgenmiştir. Kenti, yeri ve tasarımın kendisini sınırlı ve çoğu zaman alternatif okumalara kapalı bir biçimde temsil etmiştir. 19901 ylllardan itibaren ise bilgisayar teknolojilerinin gelişmesiyle birlikte haritalar daha çok üç boyutlu birer temsil ve tasarım aracı olarak kullanılmaya başlamıştır. Dahası son yıllarda haritalar üç boyutlu bir ilişkiler ağı olarak ele alınmaktadır. Bu ağ, haritalanı çoklu anlamlara ve okumalara açık hale getirmiştir. Haritalar artık bilgisayar teknolojilerinin desteklediği sanal bir ortamda oluşturulan, değiştirilen ve yeniden oluşturulan ilişkilerle geliştirilmektedir.

Ancak bu, mimarlıkta bir temsil ve tasarım aracı olarak kullanılan yaratıcı haritaların bilgisayar teknolojilerinin keşfedilmesi ve kullanım alanının genişletilmesiyle birlikte ortaya çıktığı anlamına gelmemektedir. Yine de bilgisayar destekli teknolojiler, mimarlıkta yaratıcı harita kullanımını teşvik etmekle kalmamış; tasarlama ve haritalama süreçlerinin önemli ölçüde değişmesine yol açmıştır. Mimarlıkta tasarlama ve haritalama süreçleri artık birlikte ve birbirine entegre bir biçimde yürütülmektedir. Böylece haritalama, tasarım sürecinin başında yapılan ve yüzeysel bir yer analizi; yani, yakın ve uzak çevredeki binaların, yolların, yeşil ya da açık alanların tespiti olmaktan çıkmıştır. Bununla birlikte, fiziksel öğelerin ve değişkenlerin tespitine yönelik bu analizler tasarım sürecindeki önemini korumaktadır. Ama harita yalnızca analitik bir araç olarak kullanılmamaktadır. Harita, analiz etme becerisinin yanı sıra düşünme, hayal etme ve tasarlama becerisini de kazandırmaktadır. Mimarlık alanında bu beceriyi kazanmak ve kullanmak için haritayı yalnızca yeni bir nesne, bina, kütle ya da imge değil aynı zamanda yeni bir yer oluşturmayı sağlayan bir tasarım aracı olarak görmek gerekir. Yaratıcı olmak bunu gerektirir.

Makalede mimarlık literatüründe öne çıkmış olan ziihinsel, kuramsal, anlatımsal, şekilsel, algısal, imgesel, işlevsel, diz̨insel, ilişkisel ve etkileşimsel haritalar yaratıcı haritalar olarak tartış1mıştır. Bu tartışma, yaratıcı haritalar üzerine mimarlık literatüründe bugüne kadar yapılmış olan en kapsamlı tartışmalardan biridir. Yaratıcı haritalar son yıllarda çoğunlukla ilişkisel haritalar üzerinden tartışılmaktadır. Bu makalede ise yaratıcı haritalarla daha kapsamlı bir tartışma ortaya koyulmaktadır. Yine de makalenin tartışma alanı bu haritaların tanımı, işlevi ve tasarımdaki yeriyle sınırlandırılmıştır (Tablo 1). Bununla birlikte, mimarlıkta birçok yaratıcı harita örneği bulunmaktadır. Makale kapsamında ele alınan haritalar, mimarlık alanında yaygın birer temsil ve tasarım aracı olarak kullanıldığı anlaşılan yaratıcı harita örneklerinden bazılarıdır. Ancak bu makale, harita örneklerini kategorilere ayırmak ya da bu örnekleri sınıflandırmak üzere geliştirilmemiştir. Aksine makalede bugüne kadar aralarında kesin bir ayrım olduğunu düşündürecek şekilde sınıflandırılmış olan haritaların ayrı kategoriler oluşturmadığına işaret edilmiştir. Örneğin, imge yalnızca imgesel haritalarda kullanılan bir öğe değildir. İmge birçok farklı haritada kullanılmaktadır. Kaldı ki, haritanın bir görselleştirme ve bilgilendirme aracı olduğu bilinmektedir. Harita görsel bilgiyi imge aracilığıla iletmektedir. Diğer yandan, imgesel haritalarda hayal gücü; yani, imgelem mimarllğ1, kenti, hatta dünyayı değiştirecek kadar güçlü bir biçimde dışa vurulduğu için bu haritalar imgesel haritalar olarak değerlendirilmiştir. Ayrıca haritalarda imgeler, izler ve işaretler arasında çok çeşitli ilişkiler kurulmaktadır. Bu ilişkiler yalnızca ilişkisel haritalarda değil diğer haritalarda da bulunmaktadır. Ancak ilişkisel haritalar daha çok görünmeyen ilişkilere odaklanmış ve bunları görünür hale getirmiştir. Bu haritalarda ilişkiler yeni bir görünürlük edinmiştir. 


\section{Tablo 1. Yaratıcı haritalar}

Bir Temsil ve Tasarım Arac1 Olarak Yaratıc1 Haritalar

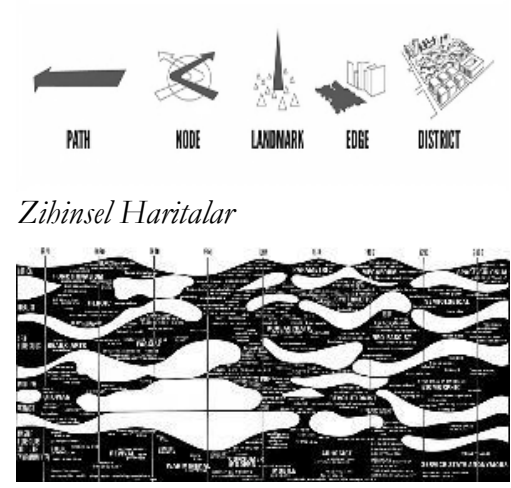

Kuramsal Haritalar

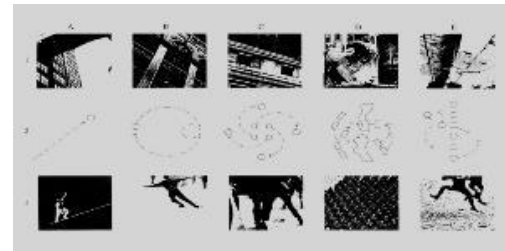

Anlatımsal Haritalar

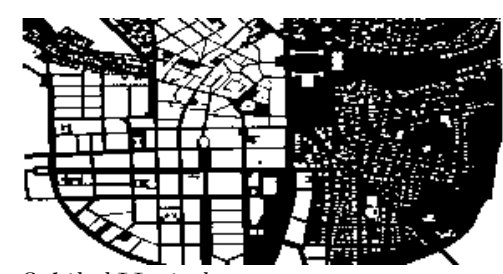

Sekilsel Haritalar

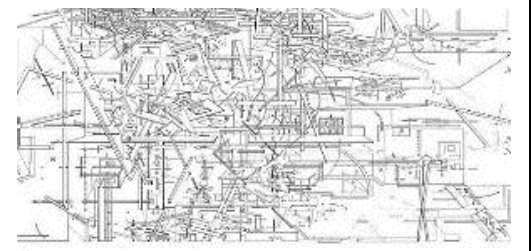

Algzsal Haritalar

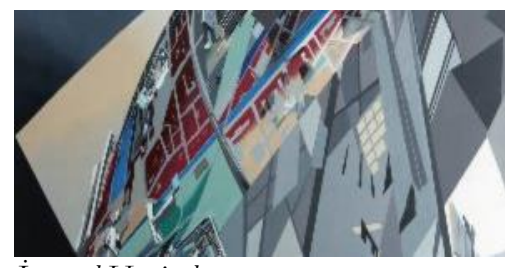

Imgesel Haritalar

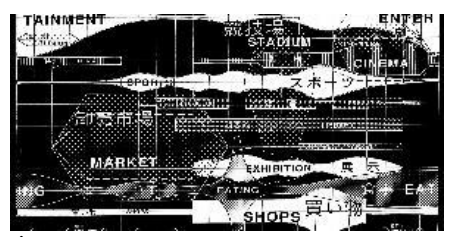

İslevsel Haritalar
Yaratıcı Haritaların Tanımı, İslevi ve Tasarım Alanındaki Yeri

Kentsel ve mimari mekânın zihinde oluşmasını ve bu oluşumun kentin bir parçası olmasını sağlar.

Kentsel ve mekânsal bir ilişkiler ağı önerir.

Mimari tasarımın kentteki yerini bulması ya da kendi yerini oluşturması için önemlidir.

Kuramsal ve tasarımsal bilginin bir araya getirildiği ve ilişkilendirildiği

haritalardır.

Mimari tasarımların kavramsal ve biçimsel olarak geliştirilmesini sağlamaktadır.

Mimari tasarımları hem geliştirmekte hem de gerekçelendirmektedir. Mimarlık bilgisinin gelişmesine aracılık etmektedir.

Mimari tasarımların bir kurguya, olaya ve anlatıya göre geliştirilmesini sağlar.

Tasarım süreci ve tasarımın kendisi hakkında görsel bilgi sunar.

Görsel bilgiyi bir anlatıya dayandırır.

Olayın ve anlatının başlıca tasarım öğesi olmasını sağlamaktadır.

Kenti şekil ve zemin ya da doluluk ve boşluk ilişkileriyle ortaya koyar. Kentsel doluluk ve boşluk ilişkilerinin tersine çevrilebileceğini gösterir. Boşlukları, doluluklar gibi, kesin ve açık bir biçimde görünür hale getirir. Boşluğun kentsel ve mekânsal tasarım sürecinin ve tasarımın kendisinin bir parçası olmasını sağlar.

Mekân algısını ve anlayışını değiştirir.

Zamansız ve yersiz bir mekân ve tasarım anlayışı geliştirir.

Mekânın ötesinde düşünmeyi gerektirir.

Mekânın ölçeğinin, merkezinin ya da işlevinin olmadığını gösterir.

Olası mekânları ya da mekânsal olasılıkları ortaya koyar.

Yeni bir kentsel ve mekânsal gerçeklik sunar.

Alternatif bir kent ve mimarlık anlayışının geliştirilmesini sağlar.

Yeni bir kentsel ve mekânsal düzen önerir.

Kentsel ve mekânsal ilişkilerin yeni bir kent imgesi yaratacak biçimde

yeniden düzenlenmesini ve tasarlanmasını gerektirir.

Mimari işlevi ve işlevsel ilişkileri ortaya koymaktadır.

Mimarlıkta yeni işlevsel ve mekânsal ilişkilerin geliştirilmesini

sağlamaktadır.

İşlevsel ilişkilerin sürekliliğini ve yeni ilişkiler oluşturma potansiyelini açığa çıkarmaktadır. 
Tablo 1'in devamı...

Bir Temsil ve Tasarım Aracı
Olarak Yaratıc1 Haritalar

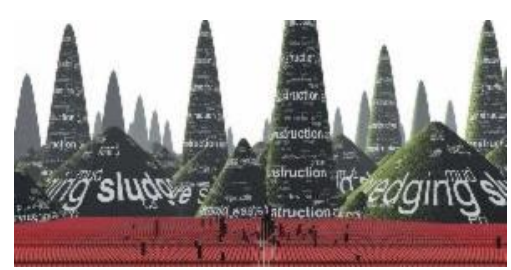

Diఇinsel Haritalar
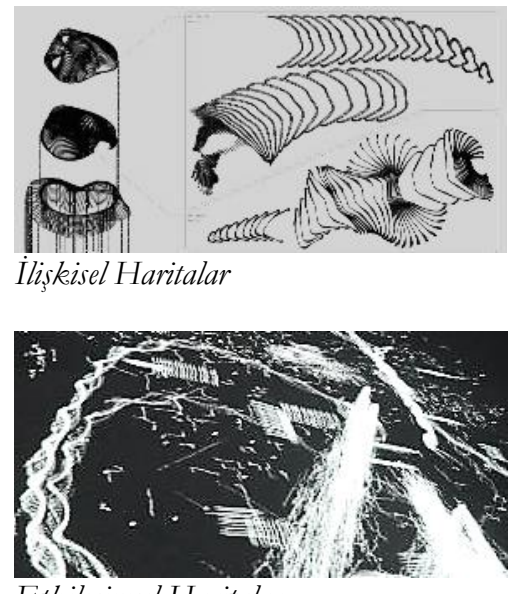

Etkileșimsel Haritalar
Yaratıcı Haritaların Tanımı, İşlevi ve Tasarım Alanındaki Yeri

İşlevsel, biçimsel ya da bağlamsal verilerin bir dizi oluşturacak biçimde işlenmesini sağlar.

İşlevsel ve mekânsal ilişsiler arasında bir dizilim oluşturur.

Mekâna dizinsel bir hareketlilik, akışkanlık ve canllı1k kazandırır.

Yeni bir canlılık anlayışının geliştirilmesini sağlamaktadır.

Canlılığın biçimsel hareketlilikten geçtiğini ortaya koymaktadır.

Biçimsel hareketliliği sağlamak için bir ilişkiler ağı oluşturmaktadır.

Mimari tasarımda üründen çok sürecin tartışılmasına neden olmaktadır.

Tasarım sürecini yönlendirecek olan potansiyel ilişkileri ortaya

koymaktadır.

Tasarımın bir ilişkiler ağı olarak oluşmasını sağlamaktadır.

Tasarımın değişim gösteren ilişkilere göre yeniden oluşmasına neden olur. Değişkenlik ve devingenlik üzerine kuruludur.

Tasarımı oluşturan ilişkileri iki ya da üç boyutlu çizimlerle ve görüntülerle ortaya koyar.

İlişkiler değiştikçe görüntülerin de değişmesini ve yeniden oluşmasını sağlar.

Etkileşimli bir değişkenlik sunar.

Yaratıcı haritalar yalnızca mimari tasarımı temsil eden değil onu oluşturan haritalardır. Burada kronolojik bir sıralamayla tartışılmış olan yaratıcı haritalar, mimarlıkta haritalama ve tasarlama süreçlerinin zaman içerisinde değiştiğini ortaya koymaktadır. Bilgisayar teknolojilerinin gelişmesi, bu değişimi desteklemiştir. Harita artık bilgisayar destekli tasarım sürecinde tasarımla birlikte oluşmakta ve tasarımı oluşturmaktadır. Bu nedenle, harita ve tasarım arasındaki temsil ilişkisi değişime uğramıştır. Bu ilişkinin değişmesi, mimarlıkta imge ile nesne arasında yaşanan ve imgenin temsil ettiği ya da imgelediği nesneden bağımsızlaşarak kendisini temsil etmesini sağlayan değişimle yakından ilişkilidir. Bu, tasarımın imgesi olmanın yanı sıra tasarımın kendisi olan; yani, tasarımı oluşturan haritanın geçirdiği en önemli değişimlerden biri olarak görülmelidir. Dolayısıyla mimarlıkta harita ve tasarım arasında bir yer değişimi yaşanmaktadır. Harita, tasarımın kendisi olarak algılanmaktadır. Hatta haritanın tasarımın kendisinden daha yaratıcı olduğu anlaşılmaktadır; çünkü haritada olan ilişkilerin olduğu gibi tasarıma aktarılması, tasarımın bu ilişkilere göre oluşturulması çoğu zaman zorlayıcı olmaktadır. Bu yüzden, harita artık tasarımdan çok kendisini temsil etmeye başlamıştır. Son yıllarda mimarlık alanında yalnızca kendisine gönderme yapan ve kendi kendisinin temsili olan tasarımların gündemde olduğu düşünülürse, bu alanda kullanılan haritaların da mimarlığın başlıca temsil araçları olarak benzer özellikler taşıyor olması şaşırtıcı değildir. Önemli olan, haritanın yalnızca temsil değil aynı zamanda tasarım aracı; yani, yaratıcı bir araç olduğunu anlamak ve bilmektir. Bu anlamda, mimarlıkta haritanın üç boyutlu bir tasarım aracı olduğunu ortaya koyan ve bunu yaratıcı harita olarak tanımlayan bu makalenin mimarlık literatürüne önemli bir katkısı olacağı düşünülmektedir. 
Stüdyolardan ofislere, mimarlıkta tasarım ortamını oluşturan her yerde haritanın bir tasarım aracı kullanılması haritaya, tasarıma ve bütünüyle mimarlığa olan bakış açısını değiştirecektir. Özellikle mimarlık eğitiminin temeli olan mimari tasarım stüdyolarında yaratıcı harita kullanımının teşvik edilmesi kendi bünyesinde ve çevresinde yeni ilişkiler kuran ya da en azından kurmaya çalışan tasarımların geliştirilmesine etki edecektir. Böylece mimari tasarımın biçimi değil biçimi oluşturan süreci ve ilişkileri tasarlamak olduğu anlaşılacaktır. Bugün mimarlıkta daha çok yeni biçimler ortaya koymakla meşgul olan öğrenciler ve tasarımcılar, haritayı görünen ve görünmeyen ilişkileri açığa çıkaran ve bu ilişkilerle tasarımı oluşturan bir araç olarak kullandıkları takdirde tasarımın biçimsel değil ilişkisel bir süreç olduğunun farkına varacaktır. Ancak bu süreçte ilişkileri haritalamak ve tasarlamak kadar bu ilişkilerin etkileşimli bir değişkenlik gösterdiğinin farkına varmak da önemlidir. Bugün insanlar, yerler, mekânlar, kültürler ve toplumlar arasındaki bilgisayar teknolojilerinin desteklediği iletişim ve etkileşim ortamı ilişkileri her zamankinden daha değişken hale getirmiştir. Böyle bir ortamda mimarlık alanında yürütülen tasarlama ve haritalama süreçlerinin aynı kalması mümkün değildir.

\section{REFERANSLAR (REFERENCES)}

Acar, Y. (2019). Bilginin haritalanması: Bilgi, ilişkilendirme ve temsil. In E. Alanyalı Aral (Ed.), Iliskkisel bir eylem olarak haritalama (pp. 19-25). Ankara: Mimarlar Odası Yayınları.

Alanyalı Aral, E. (2018). Mimarlıkta yaratıcı haritalama: Yaşanmış mekânı görünür kılmak üzerine. Mimarlı, 399(1), 1-6.

Alanyalı Aral, E. (2019). Giriş. In E. Alanyalı Aral (Ed.), Ilişskisel bir eylem olarak haritalama (pp. 1-2). Ankara: Mimarlar Odası Yayınları.

Amoroso, N. (2012). Creative mapping. Canadian Architect. Retrieved from https://www.canadianarchitect.com/creative-mapping/

Baudrillard, J. (1988). Simulacra and simulations. In M. Poster (Ed.), Selected writings (pp. 166-184). California: Stanford University Press.

Baudrillard, J. \& Nouvel, J. (2011). Tekil nesneler. İstanbul: Yem Yayınları.

Buzan, T. (2006). The mind map book. Londra: BBC Books.

Corner, J. (2011). The agency of mapping: Speculation, critique and invention. In M. Dodge, R. Kitchin, C. Perkins (Eds.), The Map Reader: Theories of Mapping Practice and Cartographic Representation (pp. 89-101). New York: Wiley \& Sons.

Dean, P. (2007). Rethinking representation. Rotterdam: Episode Publishers.

Deleuze, G. \& Guattari, F. (1980). A thousand plateaus (B. Massumi, Trans.). Minneapolis: University of Minnesota Press.

Derrida, J. (1972). Dissemination (B. Johnson, Trans.). London: The Athlone Press. 
Harley, J. B. (1989). Deconstructing the map. Cartographica, 26(2), 1-20.

Jencks, C. (2000). Architecture 2000 and beyond. New York: Wiley \& Sons.

Kipnis, J. (2001). Perfect acts of architecture. New York: The Museum of Modern Art Publications.

Kitchin, R. \& Dodge, M. (2007). Re-thinking maps. Progress in Human Geography, 31(3), 331-344.

Kitchin, R., Dodge, M. \& Perkins, C. (2011). Conceptualising mapping. In M. Dodge, R. Kitchin, C. Perkins (Eds.), The Map Reader: Theories of Mapping Practice and Cartographic Representation (pp. 1-7). New York: Wiley \& Sons.

Lynch, K. (1960). The image of the city. London: The MIT Press.

Lynn, G. (2013). Embryologic houses. In M. Carpo (Ed.), The digital turn in architecture 1992-2012 (pp. 125-130). New York: Wiley \& Sons.

Mvrdv. (2019). Metacity / Datatown. Retrieved from https://www.mvrdv.nl/projects/147/metacity-\%2F-datatown-

Office for Metropolitan Architecture. (2019). Yokohama masterplan. Retrieved from https://oma.eu/projects/yokohama-masterplan

Paez, R. (2019). Operative mapping: Map as design tools. Barcelona: Actar Publishing.

Rowe, C. \& Coetter, F. (1978). Collage city. London: The MIT Press.

Saieh, N. (2012). Venice Biennale 2012: Gateway / Norman Foster. Retrieved from https://www.archdaily.com/268890/venice-biennale-2012-gateway-norman-foster

Schumacher, P. (2011). The autopoeisis of architecture vol. I. New York: Wiley \& Sons.

Tawa, M. (1998). Mapping: Design. Architectural Theory Review, 3(1), 35-45.

Tschumi, B. (2001). The Manhattan Transcripts. In J. Kipnis (Ed.), Perfect acts of architecture (pp. 58109). New York: The Museum of Modern Art.

Woods, L. (2008). Protoarchitecture: Analogue and digital hybrids. In B. Sheil (Ed.), Architectural Design (pp. 1-6). New York: AD Publishers.

\section{ÇIKAR ÇATIŞMASI BEYANI (CONFLICT OF INTEREST STATEMENT)}

Bu çalışmada herhangi bir finansman kaynağı bulunmamıştır.

\section{YAZAR KATKI BİLDİRİMİ (AUTHOR CONTRIBUTION STATEMENT)}

Araştırmanın tamamı Gülşah Güleç tarafindan yapılmıştır. 


\section{YAZARIN BİYOGRAFİSİ (BIOGRAPHY OF AUTHOR)}

\section{Gülşah Güleç}

1984 yllında Samsun'da doğmuştur. İlk, orta ve lise öğrenimini orada tamamlamıştır. 2003-2007 yılları arasında Eskişehir'de Osmangazi Üniversitesi Mühendislik Mimarlık Fakültesi Mimarlık Bölümü’nde lisans öğrenimine devam etmiştir. Yüksek lisans (2008-2011) ve Doktora (2011-2017) öğrenimini ise Ankara'da Gazi Üniversitesi Mimarlık Fakültesi Mimarlık Bölümü'nde tamamlamıştır. Yüksek lisans tezini mimarlıkta bağlamsallık; doktora tezini mimarlıkta orijinallik üzerine yazmıştır. 2009-2018 yılları arasında Gazi Üniversitesi Mimarlık Fakültesi Mimarlık Bölümü’nde araştırma görevlisi olarak görev yapmıştır. 2018 yılından bu yana aynı bölümde öğretim görevlisi olarak çalışmaktadır. Mimari kuram, mimari tasarım, mimarlık eğitimi ve eleştirisi üzerine çeşitli ulusal ve uluslararası platformlarda yayınlanmış akademik çalışmaları bulunmaktadır. gulsahgulec@gazi.edu.tr 